\title{
Cadmium and lead ion capture with three dimensionally ordered macroporous (3DOM) hydroxyapatite
}

Supporting Information

Manuscript Number: ES 060972S

Madhavi Srinivasan ${ }^{1, *}$, Cristiano Ferraris ${ }^{2}$ and Tim White $^{1}$

${ }^{1}$ Nanyang Technological University, School of Materials Science and Engineering, Blk N4.1-01-30, Nanyang Avenue, Singapore 639798

${ }^{2}$ Unité Scientifique de Minéralogie CNRS 7160, Dept. Histoire de la Terre, Museum National d'Histoire Naturelle, 61 rue Buffon, F-75005 Paris France

*Corresponding author: Tel:(65) 67904606, Fax: (65) 67909081, email: madhavi@ ntu.edu.sg 
Page 2 of 5

Figure S1. Secondary electron images (SEI) of a) [111] face centered close packed ( $f c c$ ) polystyrene $(1 \mu \mathrm{m})$ sphere template, and b) macroporous HAp (MHAp1) annealed at $700^{\circ} \mathrm{C}$ for $6 \mathrm{~h}$.
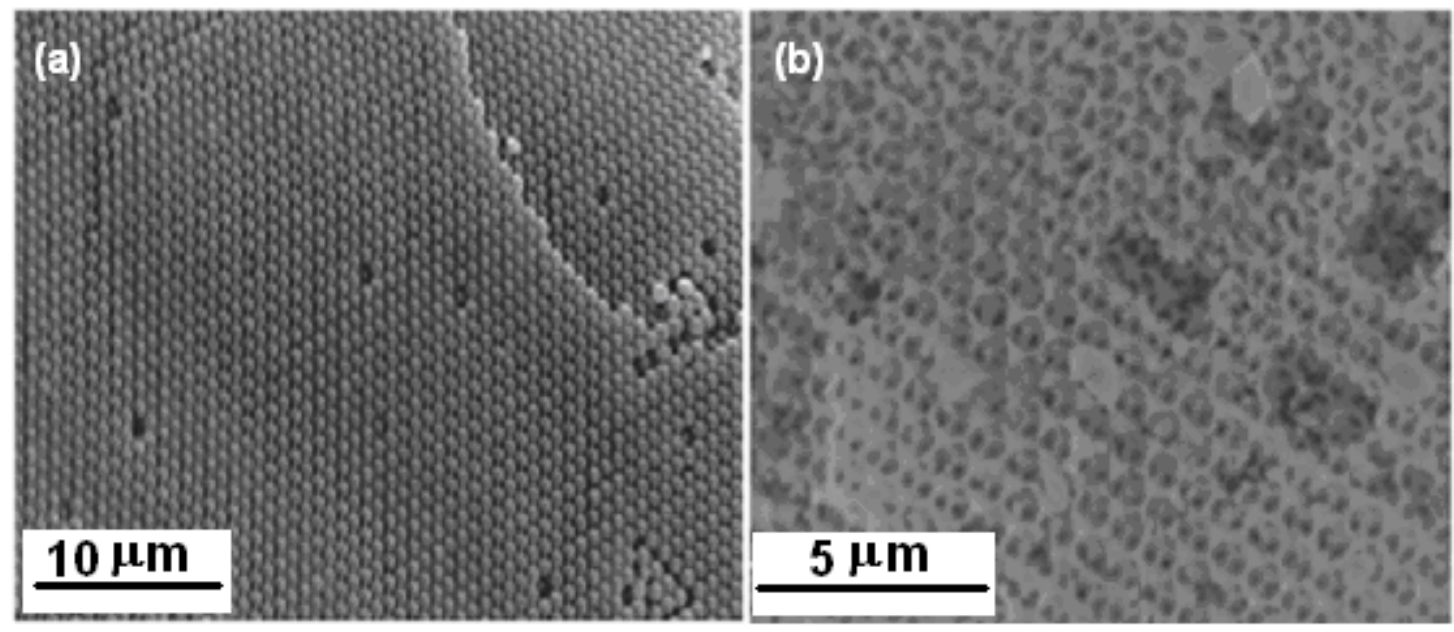
Figure S2. Representative wide scan X-ray diffraction profiles (experimental(-), calculated $\left(^{(}\right)$, and difference) of pristine a) P-HAp6 with $\mathrm{Si}$ and $\mathrm{Al}_{2} \mathrm{O}_{3}$ NIST standard and cadmium solution treated b) PHAP9 (at $80^{\circ} \mathrm{C}$ ) with 15 wt $\%$ Si NIST standard powder apatite. Bragg reflection markers from top to bottom for (a) are $\mathrm{HAp}, \mathrm{Si}, \mathrm{CaCO}_{3}$, $\mathrm{CaHPO}_{4}$ and NIST $\mathrm{Al}_{2} \mathrm{O}_{3}$ and (b) are $\mathrm{HAp}, \mathrm{CdCO}_{3}$, Si and $\mathrm{Ca}_{2} \mathrm{P}_{2} \mathrm{O}_{7}$. The $\mathrm{Si}$ and $\mathrm{Al}_{2} \mathrm{O}_{3}$ standards were added to extract unit cell parameters and amorphous content

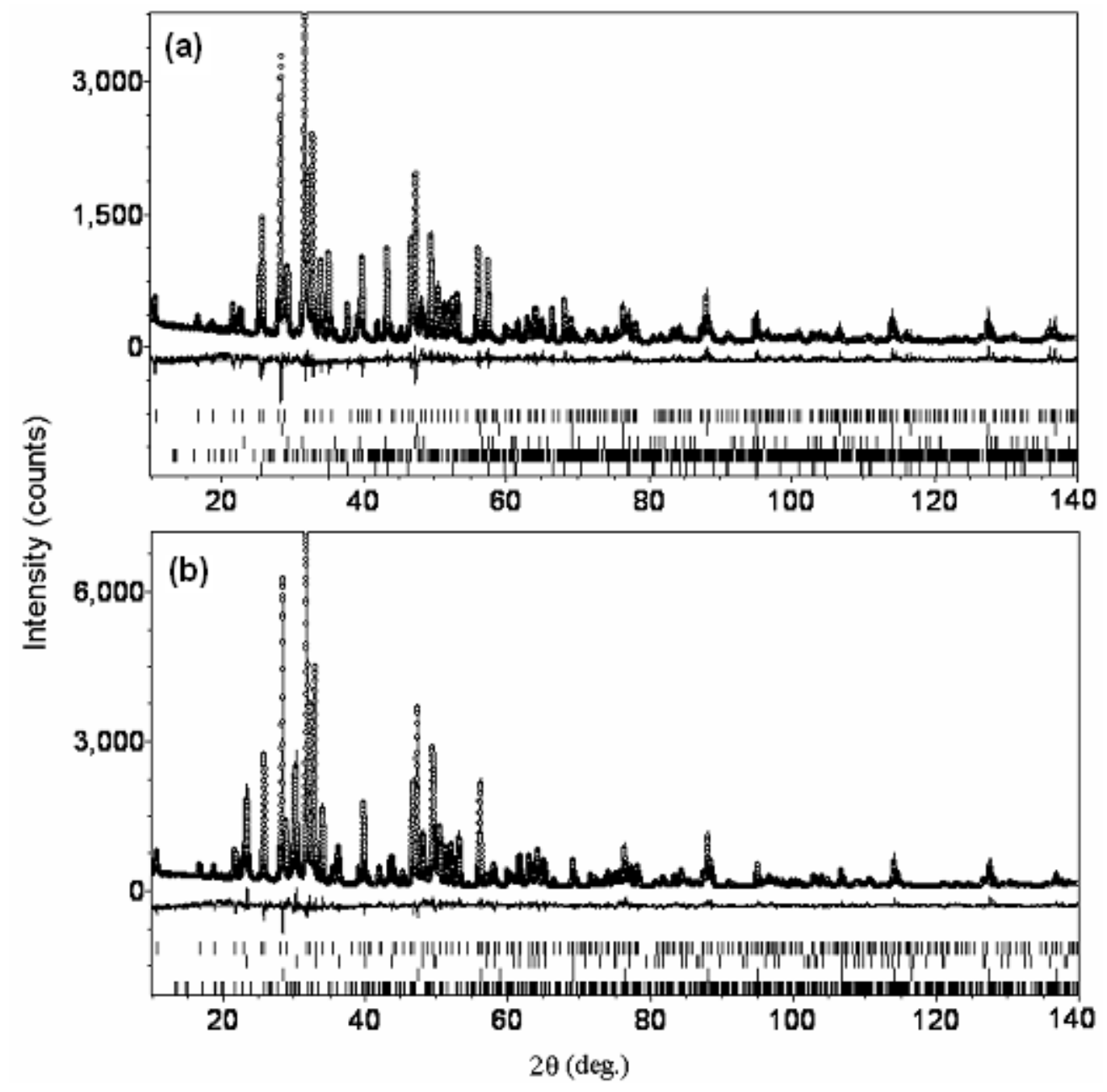


Figure S3. Representative enlarged segment of the X-ray diffraction profile (experimental(-), calculated $\left({ }^{\circ}\right)$, and difference) of 3DOM HAp after Cd solution treatment at RT (MHAP2) showing the peak fitting of each phase. Bragg reflection markers from top to bottom are $\mathrm{CdCO}_{3}\left(^{*}\right)$, monetite, $\beta-\mathrm{Ca}_{3}\left(\mathrm{PO}_{4}\right)_{2}(\#), \mathrm{CaCO}_{3}(@)$, $\mathrm{Ca}_{2} \mathrm{P}_{2} \mathrm{O}_{7}(+), \mathrm{Cd}_{2} \mathrm{P}_{2} \mathrm{O}_{7}(\mathrm{O})$, HAp. The main lines of the secondary phases are marked on the pattern.

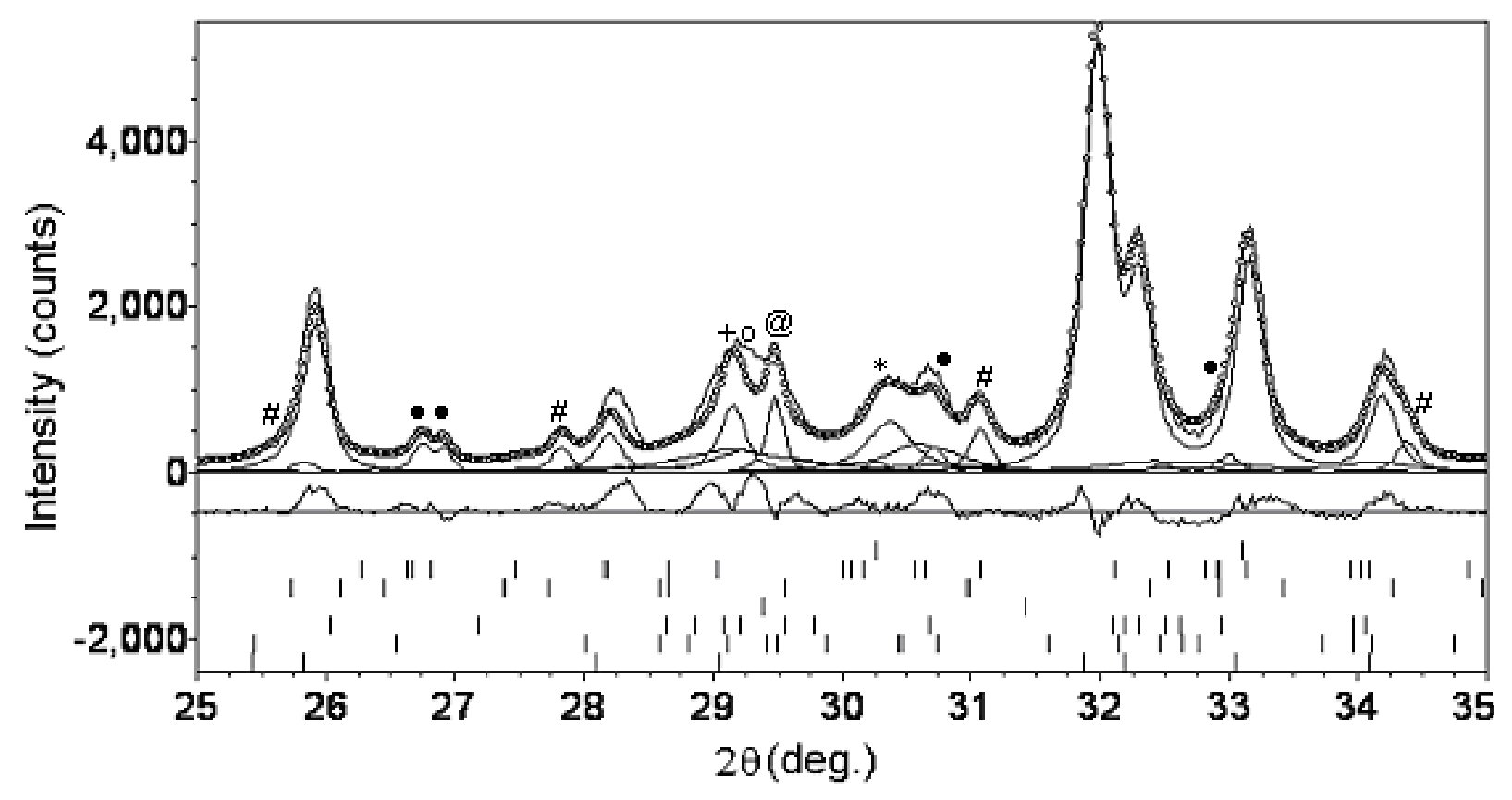


Page 5 of 5

Table S1. Quantitative phase analysis of pristine and cadmium solution treated macroporous (MHAp) and powder (PHAp) apatites uncorrected for amorphous content.

\begin{tabular}{|c|c|c|c|c|c|c|c|}
\hline \multirow[t]{2}{*}{ Sample } & \multicolumn{7}{|c|}{ Weight Percent $(\%)^{*}$} \\
\hline & $\mathrm{Ca}_{10-\mathrm{x}} \mathrm{Cd}_{\mathrm{x}}\left(\mathrm{PO}_{4}\right)_{6}(\mathrm{OH})_{2}$ & $\mathrm{Ca}_{2} \mathrm{P}_{2} \mathrm{O}_{7}$ & $\mathrm{CaCO}_{3}$ & $\mathrm{CaHPO}_{4}$ & $\beta-\mathrm{Ca}_{3}\left(\mathrm{PO}_{4}\right)_{2}$ & $\mathrm{CdCO}_{3}$ & $\mathrm{Cd}_{2} \mathrm{P}_{2} \mathrm{O}_{7}$ \\
\hline M-HAp1 & 98 & - & 1 & - & 1 & - & - \\
\hline M-HAp2 & 63 & 13 & 4 & 5 & 7 & 4 & 4 \\
\hline M-HAp3 & 65 & 7 & 4 & 8 & 9 & 5 & 3 \\
\hline M-HAp4 & 67 & 6 & 3 & 7 & 8 & 7 & 2 \\
\hline P-HAp6 & 86 & - & 12 & 2 & - & - & - \\
\hline P-HAp7 & 85 & 7 & - & - & - & 9 & - \\
\hline P-HAp8 & 90 & 3 & - & - & - & 7 & - \\
\hline P-HAp9 & 87 & 1 & - & - & - & 12 & - \\
\hline
\end{tabular}

